\title{
Recombination in Actinomyces aureofaciens
}

\author{
By S. I. ALIKHANIAN AND L. N. BORISOVA \\ The All-Union Antibiotic Research Institute, Moscow, U.S.S.R.
}

(Received 27 October 1960)

SUMMARY

Biochemical mutants of Actinomyces aureofaciens were obtained after treatment with ultraviolet irradiation or ethyleneimine. A specificity of the mutational process in a series of $A$. aureofaciens strains was observed, revealing itself mainly in formation of arginine-requiring mutants. Prototroph formation was shown to result from crosses of $\boldsymbol{A}$. aureofaciens biochemical mutants with either the same or different amino acid requirements. Colonial morphology and antibacterial activity of some prototrophs were studied.

\section{INTRODUCTION}

The possibility of obtaining hybrids or heterozygous diploids in various species of imperfect fungi was shown for the first time by Pontecorvo (1956) and others. This was extended to antibiotic-producing actinomycetes by Sermonti \& Spada-Sermonti $(\mathbf{1 9 5 5}, 1956)$ and by Sermonti (1957). Later the methods developed by these authors were used by Alikhanian \& Mindlin (1957) for obtaining recombinants in Actinomyces rimosus. The aim of this investigation was to study the possibility of hybridization in $A$. aureofaciens so as to use it for the purposes of selection.

\section{METHODS}

Biochemical mutants were obtained after ultraviolet(u.v.) irradiation and ethyleneimine treatment of Actinomyces aureofaciens. At the very beginning of our studies we found that this organism differed greatly from other actinomycetes in the extreme specificity of the mutational process in a number of strains, such as 536, II, Bd, BMK, B-16. These strains of $A$. aureofaciens differed from each other in their origin, colonial morphology and antibiotic-producing properties. The biochemical mutants were isolated on the following media: corn steep liquor (N12) medium, containing (w/v) $0.5 \%$ corn steep liquor, $0.4 \%\left(\mathrm{NH}_{4}\right)_{2} \mathrm{HPO}_{4}, \mathbf{0} \cdot \mathbf{2} \% \mathrm{KH}_{2} \mathrm{PO}_{4}$, $\mathbf{0 . 2 9} \% \mathrm{MgSO}_{4}, 0.1 \% \mathrm{CaCO}_{3}, 2 \%$ starch, $2 \cdot 0 \%$ agar; and two modifications of this medium, one with the addition of yeast extract and another with the addition of yeast extract and casein hydrolysate. The data on selection of biochemical mutants in $A$. aureofaciens are presented in Table 1.

As is evident from Table 1 our data do not conform to the regularities of biochemical mutant formation described in the literature in that from all strains, independent of the nutrient medium used, the occurrence of arginine-requiring ( $\mathrm{arg}$ ) mutants only was in general observed (99 cases), and only in two cases other amino acid requiring mutants (histidine $(h i s)$ and isoleucine + valine $(i s l+v a l)$ ) were detected. 
The occurrence of arginine-requiring mutants in almost all cases could not but direct our attention to study hybridization in Actinomyces aureofaciens. The prototrophs were obtained by the method described by Alikhanian \& Mindlin (1957).

Table 1. The frequency of isolation of biochemical mutants from different strains of Actinomyces aureofaciens treated with various mutagenic factors

\begin{tabular}{|c|c|c|c|c|c|}
\hline Strain & $\begin{array}{l}\text { Mutagenic } \\
\text { factor }\end{array}$ & Medium & $\begin{array}{l}\text { No. of } \\
\text { biochemical } \\
\text { mutants }\end{array}$ & $\begin{array}{l}\text { Nutritional } \\
\text { requirements }\end{array}$ & $\begin{array}{c}\text { No. of } \\
\text { isolates } \\
\text { examine }\end{array}$ \\
\hline \multirow[t]{6}{*}{ BMK } & u.v. radiation & N 12 & 21 & Arginine & 1300 \\
\hline & & $\mathrm{N} 12$ + yeast extract & 7 & Arginine & - \\
\hline & & $\begin{array}{c}\mathrm{N} 12+\text { yeast extract } \\
\text { and casein }\end{array}$ & 5 & Arginine & - \\
\hline & Ethyleneimine & N12 & 0 & 一 & 1075 \\
\hline & & N12+yeast extract & $\mathbf{0}$ & 一 & 一 \\
\hline & & $\begin{array}{c}\mathrm{N} 12+\text { yeast extract } \\
\text { and casein }\end{array}$ & $\mathbf{0}$ & 一 & - \\
\hline \multirow[t]{5}{*}{$\mathbf{B d}$} & u.v. radiation & $\mathrm{N} 12$ & 19 & Arginine & 1211 \\
\hline & & $\begin{array}{c}\mathrm{N} 12+\text { yeast extract } \\
\text { and casein }\end{array}$ & 4 & Arginine & - \\
\hline & Ethyleneimine & N 12 & $\mathbf{0}$ & - & 1200 \\
\hline & & N12 + yeast extract & 2 & Arginine & - \\
\hline & & $\begin{array}{c}\mathrm{N} 12+\text { yeast extract } \\
\text { and casein }\end{array}$ & 1 & Arginine & - \\
\hline \multirow[t]{6}{*}{536} & u.v. radiation & N12 & 5 & $\begin{array}{l}\text { Isoleucine + } \\
\text { valine } \\
\text { Arginine (4) }\end{array}$ & $\begin{array}{c}3319 \\
-\end{array}$ \\
\hline & & N12+yeast extract & 10 & Arginine & 一 \\
\hline & & $\begin{array}{c}\mathrm{N} 12+\text { yeast extract } \\
\text { and casein }\end{array}$ & 0 & & \\
\hline & Ethyleneimine & N 12 & 4 & Arginine & 1273 \\
\hline & & N12+yeast extract & 7 & Arginine & 一 \\
\hline & & $\begin{array}{c}\mathrm{N} 12+\text { yeast extract } \\
\text { and casein }\end{array}$ & $\mathbf{1}$ & Arginine & - \\
\hline \multirow[t]{7}{*}{ B-16 } & u.v, radiation & $\mathrm{N} 12$ & 6 & Arginine & 2006 \\
\hline & & N12 + yeast extract & 3 & Arginine & 一 \\
\hline & & N12 + yeast extract & 4 & Histidine (1) & - \\
\hline & & and casein & & Arginine (3) & 一 \\
\hline & Ethyleneimine & N12 & 0 & 一 & 1740 \\
\hline & & N12+yeast extract & 0 & 一 & - \\
\hline & & $\begin{array}{c}\mathrm{N} 12+\text { yeast extract } \\
\text { and casein }\end{array}$ & 0 & - & - \\
\hline \multirow[t]{6}{*}{ II } & u.v. radiation & N12 & 1 & Arginine & 3071 \\
\hline & & N12 + yeast extract & 0 & - & 一 \\
\hline & & $\begin{array}{c}\mathrm{N} 12+\text { yeast extract } \\
\text { and casein }\end{array}$ & $\mathbf{0}$ & - & - \\
\hline & Ethyleneimine & $\mathrm{N} 12$ & $\mathbf{0}$ & - & 1600 \\
\hline & & N12 + yeast extract & $\mathbf{0}$ & - & 一 \\
\hline & & $\begin{array}{c}\mathrm{N} 12+\text { yeast extract } \\
\text { and casein }\end{array}$ & $\mathbf{0}$ & 一 & - \\
\hline
\end{tabular}




\section{RESULTS}

It was first necessary to demonstrate the possibility of recombination in Actinomyces aureofaciens in order that crosses might be made between all argininerequiring mutants to explain their genetic nature. For this purpose we used the isoleucine + valine-requiring mutant, the histidine-requiring mutant, and a number of arginine-requiring mutants. The data on the investigation of combinations in the three groups are presented in Table 2.

Table 2. Biochemical mutant combinations and the frequency of prototroph formation from these combinations

\begin{tabular}{|c|c|c|c|}
\hline $\begin{array}{l}\text { Combination } \\
\text { group }\end{array}$ & $\begin{array}{l}\text { Biochemical } \\
\text { combination }\end{array}$ & $\begin{array}{c}\text { Prototroph } \\
\text { frequency } \\
(\%)\end{array}$ & $\begin{array}{c}\text { Frequency } \\
\text { biochemical } \\
\text { mutant } \\
\text { reversions }\end{array}$ \\
\hline I & 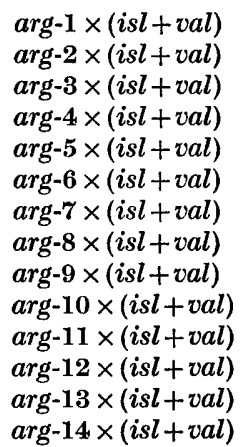 & $\begin{array}{l}0 \cdot 13 \\
0 \cdot 06 \\
0 \cdot 0009 \\
3 \cdot 3 \\
0 \cdot 0004 \\
0 \cdot 13 \\
0 \cdot 01 \\
0 \cdot 03 \\
0 \cdot 006 \\
0 \cdot 0 \\
0 \cdot 004 \\
0 \cdot 02 \\
0 \cdot 0025 \\
0 \cdot 0003\end{array}$ & $\begin{array}{l}0 \\
0 \\
0 \\
0 \\
0 \\
0 \\
0 \\
0 \\
0 \\
0 \\
0 \\
0 \\
0 \\
0\end{array}$ \\
\hline II & $\begin{array}{l}\text { arg- } 2 \times \text { his } \\
\text { arg-7 } \\
\text { his }\end{array}$ & $\begin{array}{l}0.0015 \\
0.0007\end{array}$ & $\begin{array}{l}0 \\
0\end{array}$ \\
\hline III & $h i s \times(i s l+v a l)$ & 0.9 & $\mathbf{0}$ \\
\hline
\end{tabular}

Biochemical mutants arg-1 to arg-5 were derived from strain Bd; arg-6 to arg-14 from strain BMK; (isl +val) from strain 536; his from strain B-16.

It should be pointed out that these crosses gave rise to a comparatively high frequency of prototrophs, reaching $\mathbf{3 \cdot 3} \%$ in some combinations. This was higher than the frequencies observed in crosses of Actinomyces rimosus.

The prototrophs, obtained from the various combinations, independent of the starting strains, belonged morphologically to the classical wild-type strain of A. aureofaciens as for example strain 536 type. Such prototrophs formed flat colonies of mouse-grey or dark-grey coloration with aerial mycelium and buff-yellow substrate mycelium. Some prototrophs were characterized by a different rate of sporulation but this cannot serve as a distinguishing feature. Prototrophs from combination arg-7 $\times$ his may be regarded as an exception, since they were characterized by dingy-beige coloured spores and low rate of sporulation.

In contrast, the biochemical mutants from which the prototrophs were derived differed greatly in colonial morphology from the wild-type strains. Thus, all argininerequiring mutants were characterized by flat colonies, not highly folded or having radial lines, asporogenic, with no aerial mycelium or specific pigment (Plate 1). The histidine-requiring mutant formed light-grey, flat, compact colonies, elevated above 
the agar surface and characterized by a low rate of sporulation and limited growth. The mutant requiring isoleucine and valine differed from the wild-type strains only by the production of colonies with poor sporulation and a broad asporogenic periphery.

\section{Segregation patterns of prototrophs}

The prototrophic recombinants gave rise to various types of segregants with differing frequencies. In order to study in detail the various segregation patterns we used prototrophs from eleven combinations, eight combinations of group I (arg-1 to

Table 3. Distribution of prototrophs from combinations according to the segregation types

\begin{tabular}{|c|c|c|c|}
\hline $\begin{array}{l}\text { Combination } \\
\text { group }\end{array}$ & $\begin{array}{l}\text { Biochemical mutant } \\
\text { combination }\end{array}$ & $\begin{array}{l}\text { Prototrophs } \\
\text { studied }\end{array}$ & $\begin{array}{l}\text { Segregation } \\
\text { type }\end{array}$ \\
\hline \multirow[t]{8}{*}{ I } & $\arg -1 \times(i s l+v a l)$ & $\begin{array}{l}\text { No. } 1 \\
\text { No. } 2 \\
\text { No. } 3 \\
\text { No. } 4 \\
\text { No. } 5\end{array}$ & $\begin{array}{l}\text { I } \\
\text { I } \\
\text { I } \\
\text { II } \\
\text { VI }\end{array}$ \\
\hline & $\arg -2 \times(i s l+v a l)$ & $\begin{array}{l}\text { No. } 1 \\
\text { No. } 2 \\
\text { No. } 3 \\
\text { No. } 4 \\
\text { No. } 5 \\
\text { No. } 6 \\
\text { No. } 7\end{array}$ & $\begin{array}{l}\text { I } \\
\text { I } \\
\text { I } \\
\text { IV } \\
\text { VI } \\
\text { VI } \\
\text { VI }\end{array}$ \\
\hline & $\arg -3 \times(i s l+v a l)$ & $\begin{array}{l}\text { No. } 1 \\
\text { No. } 2 \\
\text { No. } 3\end{array}$ & $\begin{array}{l}\text { I } \\
\text { II } \\
\text { III }\end{array}$ \\
\hline & $\arg -4 \times(i s l+v a l)$ & $\begin{array}{l}\text { No. } 1 \\
\text { No. } 2\end{array}$ & I \\
\hline & $\arg -5 \times(i s l+v a l)$ & $\begin{array}{l}\text { No. } 1 \\
\text { No. } 2 \\
\text { No. } 3\end{array}$ & $\begin{array}{l}\text { I } \\
\text { I } \\
\text { II }\end{array}$ \\
\hline & $\arg -6 \times(i s l+v a l)$ & $\begin{array}{l}\text { No. } 1 \\
\text { No. } 2 \\
\text { No. } 3 \\
\text { No. } 4 \\
\text { No. } 5\end{array}$ & $\begin{array}{l}\text { I } \\
\text { I } \\
\text { I } \\
\text { IV } \\
\text { IV }\end{array}$ \\
\hline & $\arg -7 \times(i s l+v a l)$ & $\begin{array}{l}\text { No. } 1 \\
\text { No. } 2 \\
\text { No. } 3\end{array}$ & $\begin{array}{l}\text { I } \\
\text { I } \\
\text { V }\end{array}$ \\
\hline & $\arg -8 \times(i s l+v a l)$ & No. 1 & IV \\
\hline \multirow[t]{2}{*}{ II } & arg-2 $\times$ his & $\begin{array}{l}\text { No. } 1 \\
\text { No. } 2 \\
\text { No. } 3 \\
\text { No. } 4 \\
\text { No. } 5\end{array}$ & $\begin{array}{l}\text { I } \\
\text { II } \\
\text { VI } \\
\text { VI } \\
\text { VI }\end{array}$ \\
\hline & arg- $7 \times$ his & $\begin{array}{l}\text { No. } 1 \\
\text { No. } 2\end{array}$ & I \\
\hline III & $h i s \times(i s l+v a l)$ & $\begin{array}{l}\text { No. I } \\
\text { No. } 2 \\
\text { No. } 3 \\
\text { No. } 4 \\
\text { No. } 5\end{array}$ & $\begin{array}{l}\text { III } \\
\text { VI } \\
\text { VI } \\
\text { VI } \\
\text { VI }\end{array}$ \\
\hline
\end{tabular}


$\arg -8 \times(i s l+v a l)$ and all combinations of group II $(\arg -2 \times h i s ; \arg -7 \times h i s)$ and group III $(h i s \times(i s l+v a l))$. As a result of this study the segregation patterns which are summarized in Table 3 were observed.

In all, the behaviour of $\mathbf{4 1}$ prototrophs from eleven combinations were studied. As far as their segregation pattern is concerned, six types were observed which were produced to a varying extent from each combination.

Segregation of type $I$. When plated out, the prototrophs of this type resembled the starting prototrophs, but segregated one of the starting biochemical mutants, in this instance the arginine-requiring mutant, but only in very small amounts $(0 \cdot 02-0.7 \%)$.

The arginine-requiring segregant in its turn segregated in the first and sometimes in the second generation a few prototrophic colonies $(0.5 \%)$, morphologically similar to the arginine-requiring mutant. Further segregation of such colonies was not observed. It should be noted that the arginine-requiring mutants never segregated prototrophic or other auxotrophic forms. Neither were reverse spontaneous mutations observed.

Segregation of type II. A considerably smaller number of the prototrophs segregated the other parental form, that is the form similar to the isoleucine + valinerequiring mutant. The amount of such segregants was 1.5 to $0.14 \%$.

The isoleucine + valine-requiring segregant in further generations segregated no new forms.

Segregation of type III. A single prototroph (one prototroph among 41 prototrophs studied) which segregated both parental biochemical mutants $(1 \cdot 4$ to $0 \cdot 1 \%$ ).

Segregation of type $I V$. In this type of segregation, the prototroph segregated morphologically changed prototrophs. The number of such prototrophs was not high $(0 \cdot 15 \%)$. In most cases, asporogenic forms similar to the arginine-requiring mutant were observed. Sometimes solid colonies with black substrate mycelium and various degrees of sporulation were encountered.

Table 4. Quantitative distribution of prototrophs according to the segregation types

$\begin{array}{cc}\begin{array}{c}\text { Segregation } \\ \text { type }\end{array} & \begin{array}{c}\text { No. of } \\ \text { prototrophs }\end{array} \\ \text { I } & 18 \\ \text { II } & 4 \\ \text { III } & 2\end{array}$

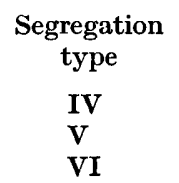

No. of
prototrophs
5
1
11

Segregation of type $V$. In the first generation prototrophs belonging to this type segregated only morphologically-changed prototrophs, while in the second generation segregation of arginine-requiring variants was also observed.

Segregation of type VI. Prototrophs of type VI proved to be stable and segregated no new forms in a number of generations. The quantitative distribution of all 41 prototrophs according to these six types of segregation is presented in Table 4. As is evident from Table 4, the prototrophs belonging to type $I$, as well as stable prototrophs were the most common.

It should be pointed out that prototrophs segregating according to different types were detected from the same combination. Thus, five prototrophs obtained from the combination arg-7 $\times(i s l+v a l)$ segregated according to three segregation types. Three of them belonged to type I, one to type II, and one to type VI. 


\section{Antibacterial activity of prototrophs}

110 prototrophic colonies were studied with respect to the amount of chlortetracycline produced. The antibacterial activity was estimated on submerged cultures by the colorimetric assay method after acid hydrolysis of the culture fluid. Biochemical mutants and the wild-type strains, from which they were derived, served as the controls. The activity of the biochemical mutants was never greater than $100 \mu \mathrm{g} . / \mathrm{ml}$. , the activity of the arginine-requiring mutants in most cases being equal to zero, while the activity of the wild-type strains was $850-1000 \mu \mathrm{g} . / \mathrm{ml}$. The activity of all prototrophs was many times higher than that of the biochemical mutants and reached the activity of the starting strains. Sometimes the activity of all the prototrophs from one combination was higher than that of the starting strains by $5-20 \%$. Examples of the antibacterial activity of prototrophs from three combinations $(\arg -1 \times(i s l+v a l) ; \arg -4 \times(i s l+v a l) ; \arg -3 \times(i s l+v a l))$ are presented in Table 5 and the corresponding diagram (Fig. 1).

The activity of prototrophs from combinations arg-2 $\times(i s l+v a l) ; \arg -7 \times(i s l+v a l)$; arg-8 $\times(i s l+v a l) ; \operatorname{arg-5} \times(i s l+v a l)$, arg- $7 \times h i s ; h i s \times(i s l+v a l)$ was no higher than that of any of the wild-type strains similar to the activity of prototrophs from combination $\arg -4 \times(i s l+v a l)$. Some prototrophs from combinations arg-6 $\times(i s l+v a l)$ and $\arg -2 \times(i s l+v a l)$ were superior with respect to their activity as compared with the wild-type strains, resembling those prototrophs from combination $\arg -1 \times(i s l+v a l)$. Combination arg-3 $\times(i s l+v a l)$ was theonly oneamong the eleven combinations studied, which produced prototrophs always superior in their chlortetracycline activity to the wild-type strains.

Table 5. Chlortetracycline activity of the wild-type strains, biochemical mutants and prototrophs from combinations arg- $4 \times(i s l+v a l)$, arg- $1 \times(i s l+v a l)$ and arg- $3 \times(i s l+v a l)$

\begin{tabular}{|c|c|c|c|}
\hline Strain & $\begin{array}{l}\text { Activity } \\
(\mu \mathrm{g} \cdot / \mathrm{ml} .)\end{array}$ & Strain & $\begin{array}{l}\text { Activity } \\
(\mu \mathrm{g} \cdot / \mathrm{ml} .)\end{array}$ \\
\hline Bd & 990 & arg-1 & $\mathbf{0}$ \\
\hline 536 & 850 & arg-3 & $\mathbf{0}$ \\
\hline $\arg -4$ & 0 & $(i s l+v a l)$ & 50 \\
\hline \multicolumn{4}{|c|}{ Prototrophs from combination $a r g-4 \times(i s l+v a l)$} \\
\hline No. 1 & 351 & No. 6 & 316 \\
\hline No. 2 & 814 & No. 7 & 582 \\
\hline No. 3 & 732 & No. 8 & 632 \\
\hline No. 4 & 707 & No. 9 & 420 \\
\hline No. 5 & 802 & No. 10 & 772 \\
\hline \multicolumn{4}{|c|}{ Prototrophs from combination $\arg -1 \times(i s l+v a l)$} \\
\hline No. 4 & 678 & No. 9 & 1086 \\
\hline No. 5 & 256 & No. 10 & 1143 \\
\hline No. 6 & 884 & No. 11 & 1062 \\
\hline No. 7 & 241 & No. 15 & 326 \\
\hline No. 8 & 466 & No. 17 & 391 \\
\hline \multicolumn{4}{|c|}{ Prototrophs from combination $a r g-3 \times(i s l+v a l)$} \\
\hline No. 1 & 1199 & No. 9 & 1288 \\
\hline No. 2 & 1038 & No. 11 & 1223 \\
\hline No. 3 & 1152 & No. 14 & 1080 \\
\hline No. 5 & 1288 & No. 16 & 1109 \\
\hline No. 7 & 1203 & No. 17 & 996 \\
\hline
\end{tabular}


It is interesting to note that in the combinations $\arg -4 \times(i s l+v a l), \arg -1 \times(i s l+v a l)$ and $a r g-3 \times(i s l+v a l)$, all of which produced prototrophs differing in antibacterial activity, one and the same isoleucine + valine requiring mutant, derived from strain 536, was used. As the other crossing component in these combinations, one of the arginine-requiring mutants, arg-4, arg-3 or arg-1 derived from strain $\mathrm{Bd}$, was used. These mutants differed neither in colonial morphology, nor in antibacterial activity. In addition to the arginine deficiency, each of these mutants is likely to possess specific physiological properties which determine the difference of the
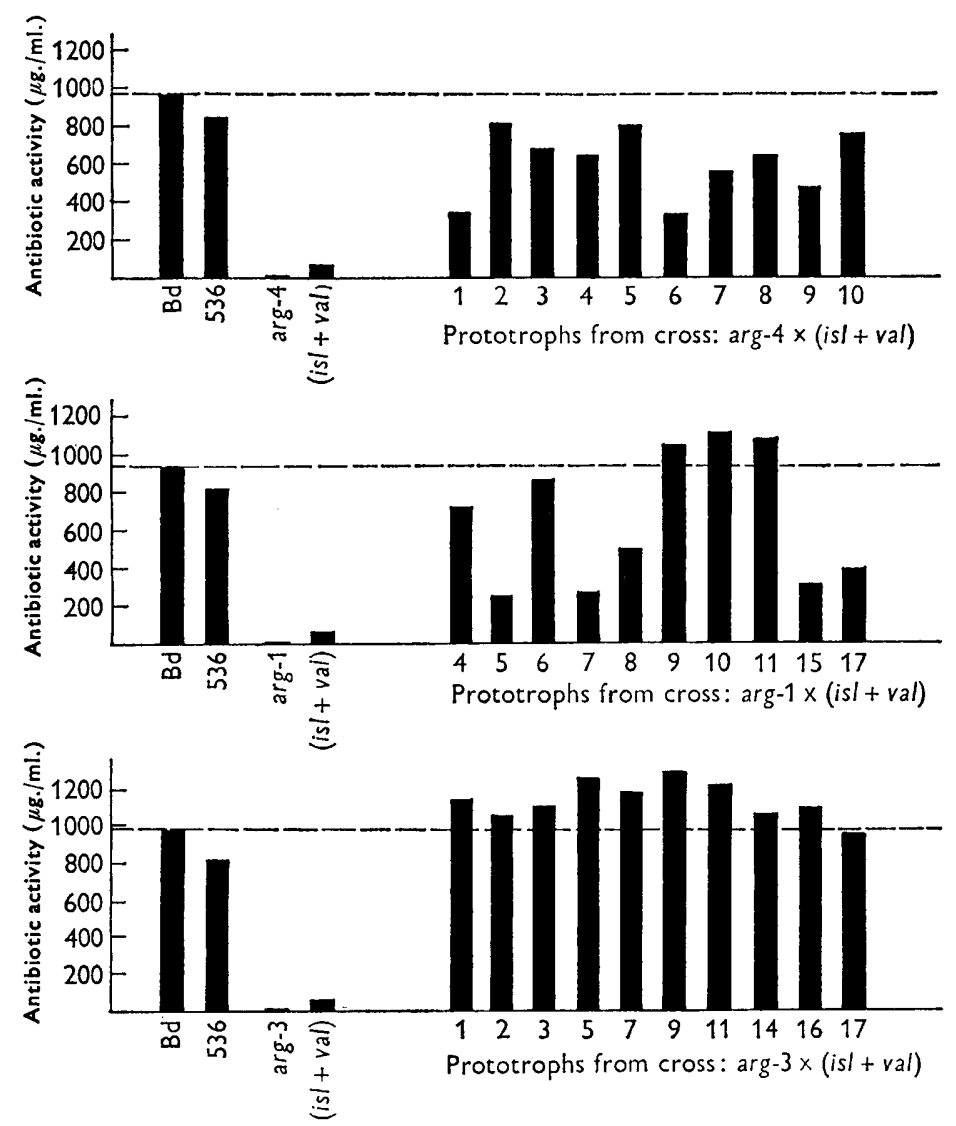

Fig. 1. Antibiotic (chlortetracycline) activity of the wild-type strains, biochemical mutants and prototrophs. The activity levels are presented in absolute values. The interrupted line indicates the highest activity level of the wild-type strains.

prototrophs from the above combinations with respect to their antibacterial activities.

One prototroph which proved to be the most active, that is prototroph no. 11 from combination arg-3 $\times(i s l+v a l)$, was selected for studying the range of induced variation in comparison with the wild-type strains. Antibacterial activity of the prototrophic-segregants was also studied. Usually the activity of non-sporulating prototrophs similar in their morphological properties to the arginine-requiring 
mutants was zero, while the activity of segregants, such as segregant no. 3 from combination arg-7 $\times(i s l+v a l)$ reached $300 \mu \mathrm{g} . / \mathrm{ml}$. After these experiments, demonstrating recombinant formation in Actinomyces aureofaciens, combinations within the arginine-requiring mutants were studied.

In these combinations 56 arginine-requiring mutants of the 99 mutants isolated were used. All these strains were very similar in colonial morphology. They were characterized by asporogenic flat colonies, not highly folded nor having radial lines, and with no aerial mycelium or specific pigment.

Table 6. Combinations of arginine-requiring mutants from which prototrophs were obtained

No reversions of arginine-requiring strains were obtained

$\begin{array}{lcc}\text { Combination } & \begin{array}{c}\text { Biochemical } \\ \text { mutant combination* }\end{array} & \begin{array}{c}\text { No. of } \\ \text { prototrophs } \\ \text { obtained }\end{array} \\ \text { No. 24 } & \begin{array}{c}\text { arg-19 } \times \text { arg-20 } \\ \text { arg-21 } \times \text { arg-9 }\end{array} & 8 \\ \text { No. 25 } & \text { arg-24 } \times \text { arg-23 } & 2 \\ \text { No. 52 } & \text { arg-15 } \times \text { arg-1 } & 1 \\ \text { No. } 1108 & \text { arg-18 } \times \text { arg-3 } & 1 \\ \text { No. } 1073 & \text { arg-15 } \times \text { arg-16 } & 1 \\ \text { No. } 1107 & \text { arg-11 } \times \text { arg-17 } & 1 \\ \text { No. } 1176 & \text { arg-11 } \times \text { arg-1 } & 1 \\ \text { No. } 958 & \text { arg-7 } \times \text { arg-22 } & 2 \\ \text { No. } 1167 & \text { arg-23 } \times \text { arg-22 } & 1 \\ \text { No. } 1155 & \text { arg-25 } \times \text { arg-23 } & 2 \\ \text { No. } 306 & \end{array}$

* Biochemical mutants arg-7; arg-9; arg-11; arg-15; arg-18; arg-19; arg-20; arg-21 ; arg-23; arg-24, were derived from strain $\mathrm{BMK}$; arg-1; arg-3; arg-16; arg-17 and arg-25 from strain $\mathrm{Bd}$; arg-22 from strain B-16.

The strains are very stable and segregate neither prototrophic, nor auxotrophic forms over a number of generations. An attempt was made to differentiate the mutants with respect to their requirements for intermediary products of arginine biosynthesis, that is for either glutamic acid, ornithine or citrulline; or according to an alternative way of synthesis, for urea or guanidine. It was found that all the arginine-requiring mutants isolated were similar in that the addition of any of the above intermediates to the medium did not restore the synthesis of arginine and permit growth. 1540 combinations of arginine-requiring mutants were studied. Prototrophs were obtained in eleven cases (Table 6). The frequency of prototrophs in these combinations is as low as 1 in $10^{7}$.

The prototrophs obtained differed in colonial morphology from one another and from strain 536 typical of Actinomyces aureofaciens. Most of them formed well sporulating colonies of white to light-grey coloration, with sporophores in the form of spirals with $0 \cdot 5-1 \cdot 0 \mu$ coils, which is characteristic of $A$. aureofaciens. Some prototrophs formed asporogenic colonies, morphologically similar to those produced by arginine-requiring mutants (Plate 1).

The study of these prototrophs with respect to their segregation pattern showed that the majority of them were stable and segregated no new forms in a number of generations. Only one prototroph, that is no. 1073, segregated a small amount $(0 \cdot 3 \%)$ of non-sporulating prototrophs. Therefore we had no data, with respect to 
direct segregation of the starting biochemical mutants, to indicate the deviation of these prototrophs by recombination. However, certain changes were found in the antibiotic-producing properties of these prototrophs as compared with the arginine requiring mutants (Table 7).

Table 7. Antibacterial activity of the wild-type strains, arginine-requiring mutants, and prototrophs from combinations of these mutants

\begin{tabular}{|c|c|c|c|}
\hline Strain & $\begin{array}{l}\text { Chlortetra- } \\
\text { cycline activity } \\
(\mu \mathrm{g} . / \mathrm{ml} .)\end{array}$ & Strain & $\begin{array}{l}\text { Chlortetra- } \\
\text { cycline activity } \\
(\mu \mathrm{g} . / \mathrm{ml} .)\end{array}$ \\
\hline \multicolumn{4}{|c|}{ Starting strains } \\
\hline $\begin{array}{l}\text { BMK } \\
\text { Bd }\end{array}$ & 950 & B-16 & 1600 \\
\hline Bd & 990 & & \\
\hline \multicolumn{4}{|c|}{ Arginine-requiring mutants } \\
\hline arg-24 & $\mathbf{0}$ & $\arg -7$ & 20 \\
\hline arg-23 & 80 & arg-22 & 0 \\
\hline $\arg -15$ & $\mathbf{0}$ & Prototrophs from & \\
\hline arg-1 & 80 & arg-23 $\times$ arg-24 & $\mathbf{0}$ \\
\hline arg-18 & $\mathbf{0}$ & $\arg -1 \times$ arg-15 & $\mathbf{0}$ \\
\hline arg-3 & 0 & $\arg -18 \times$ arg-3 & $\mathbf{0}$ \\
\hline $\arg -11$ & 20 & $\arg -11 \times \arg -17$ & $\mathbf{0}$ \\
\hline $\arg -17$ & 16 & arg-7 $\times$ arg-22 & $\mathbf{0}$ \\
\hline
\end{tabular}

\section{DISCUSSION}

As is evident from the data presented in Table 6, 16 arginine-requiring mutants out of 56, on crossing in definite combinations, produced the parental form, that is gave rise to prototrophs. It is possible to assume that they belong to different alleles, though probably not to different genes. All prototrophs from combinations of arginine-requiring mutants independent of the activity of the wild-type strains were unable to synthesize chlortetracycline. This was not observed in the other crossings of Actinomyces aureofaciens involving mutants having dissimilar biochemical requirements and many crossings of $A$. rimosus. When $A$. aureofaciens mutants with different nutritional requirements were crossed, even when the antibacterial activity of these mutants was either zero or as low as $50 \mu \mathrm{g} . / \mathrm{ml}$, the prototrophs obtained were similar in their activity to the wild-type strains. On the basis of these data it is possible to assume that the arginine-producing locus is related to the chlortetracycline-producing locus. This assumption is confirmed by the specificity of biochemical mutant formation in $A$. aureofaciens, as well as by the fact that active hybrids are formed only in combinations, where one of the crossing components is a biochemical mutant requiring histidine or isoleucine + valine. It should be noted that the data presented are preliminary, and further studies on argininerequiring mutants are needed.

\section{REFERENCES}

Alikhanian, S. I. \& Mindlin, S. Z. (1957). Recombinations in Streptomyces rimosus. Nature, Lond. 180.

Ponteconvo, G. (1956). The parasexual cycle in fungi. Annu. Rev. Microbiol. 10, 394, 400.

Sermonti, G. \& Spada-Sermonti, I. (1955). Genetic recombination in Streptomyces. Nature, Lond. 176, 121. 
Sermonti, G. \& Spada-Sermonti, I. (1956). Gene recombination in Streptomyces coelicolor. J. gen. Microbiol. 15, 609.

Sermonti, G. (1957). Produzione di penicillina da diploidi eterozigoti di Penicillium chrysogenum. Convengo di Genetica Atti III Riunione A.G.L. Suppl. La ricerca scient. pp. 3-10.

\section{EXPLANATION OF PLATE}

Colonies of arginine-requiring mutants and of prototrophs obtained from combinations of argininerequiring mutants. Grown on medium $\mathrm{N} 12$ for 8 days. 

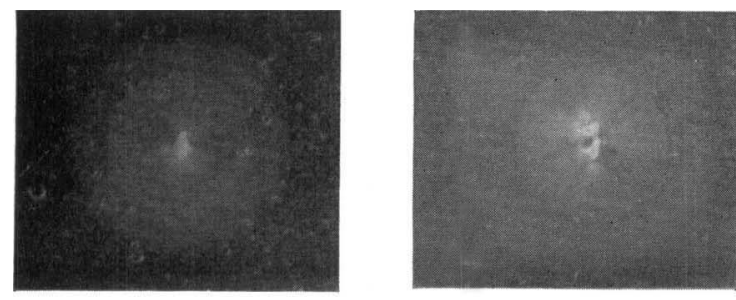

Arginine-requiring mutants
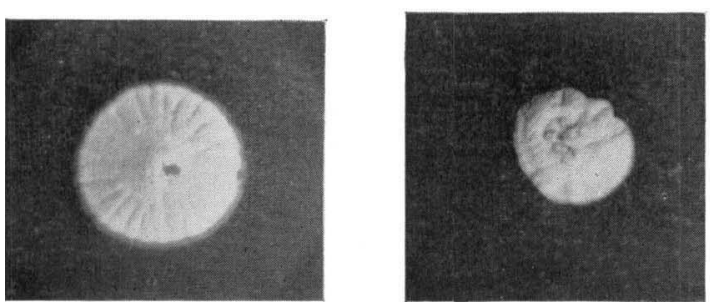

Prototrophs obtained from combinations of arginine-requiring mutants
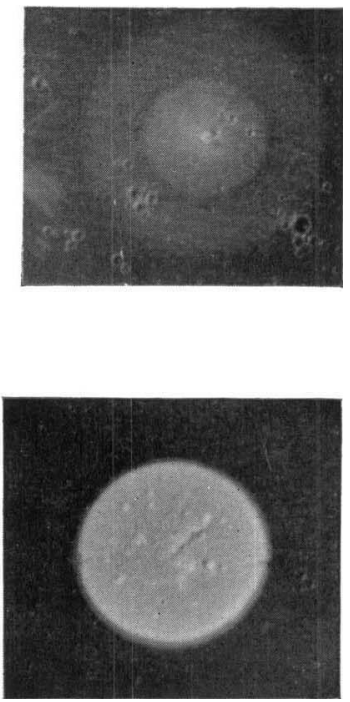